\title{
Abrasion Resistance of Thermally and Chemically Modified Timber
}

\section{Otpornost toplinski i kemijski modificiranog drva na habanje}

\author{
Original scientific paper • Izvorni znanstveni rad \\ Received-prispjelo: 29. 3. 2018. \\ Accepted-prihvaćeno: 10. 12. 2019. \\ UDK: $630 * 812.733 ; 630 * 841.61$ \\ doi: 10.5552/drvind.2019.1813
}

\begin{abstract}
Wood modification is an appropriate way of improving the natural durability and dimensional stability of wood without the use of biocides. Different thermal and chemical wood modification processes are available for this purpose, very differently affecting the structural integrity of wood. In this study, thermally modified, melamine resin treated, acetylated, furfurylated, and mDMDHEU treated wood underwent abrasion tests according to two different methods representing different loads in practice. The Taber Abraser method caused crosswise cutting into the wood surface, while the Shaker method challenged mainly the specimen edges with dynamic loads. Abrasion resistance of wood was affected by all types of cell wall modification, but the effects were strongly dependent on the type of modification and the applied load type. For characterising the suitability of wooden materials with respect to wear resistance under outdoor conditions, it is recommended to apply a set of methods rather than a single test procedure to fully reflect the loads occurring in practice.
\end{abstract}

Keywords: flooring, chemical wood modification, Shaker method, Taber Abraser, thermally modified wood, wear

SAŽETAK • Modifikacija drva prikladan je način poboljšanja njegove prirodne trajnosti i dimenzijske stabilnosti bez upotrebe biocida. Za tu namjenu dostupni su različiti postupci toplinske $i$ kemijske modifikacije, ali oni vrlo različito utječu na strukturni integritet drva. U ovom su istraživanju toplinski modificirano drvo, drvo modificirano melaminskom smolom, acetilirano i furfurilirano drvo te drvo modificirano mDMDHEU-om podvrgnuti ispitivanju otpornosti na habanje, i to primjenom dviju različitih metoda koje u praksi rezultiraju različitim opterećenjima. Metoda Taber abraser uzrokovala je poprečno habanje površine drva, a metoda Shaker dinamičkim je opterećenjima uglavnom prouzročila habanje rubova uzoraka. Na otpornost drva na habanje utjecale su sve vrste modifikacija drvnih stanica, ali učinci su izrazito ovisili o vrsti modifikacije i vrsti opterećenja. Za karakterizaciju prikladnosti drvnih materijala s obzirom na otpornost na habanje u vanjskim uvjetima preporučuje se primijeniti skup metoda, što je bolje od primjene samo jedne vrste ispitivanja kako bi se u potpunosti simulirala opterećenja koja se pojavljuju u praksi.

Ključne riječi: podovi, kemijska modifikacija drva, metoda Shaker, metoda Taber abraser, toplinski modificirano drvo, habanje

\footnotetext{
${ }^{1}$ Authors are researchers at University of Goettingen, Faculty of Forest Sciences and Forest Ecology, Department of Wood Biology and Wood Products, Goettingen, Germany.

${ }^{1}$ Autori su istraživači na Sveučilištu u Goettingenu, Fakultet šumarstva i šumarske ekologije, Zavod za biologiju drva i drvne proizvode, Goettingen, Njemačka.
} 


\section{INTRODUCTION}

\section{UVOD}

Wood modification aims at the improvement of different wood properties such as dimensional stability and natural durability without using biocides. Some types of impregnation modifications also have the potential to increase elasto-mechanical properties of wood (e.g. Lande et al., 2004, Behr et al. 2017). Some, such as thermal modification, have a negative effect on the latter because the wood becomes more brittle (Tjeerdsma et al., 1998, Epmeier et al., 2004, Shida and Saito, 2007, Brischke et al., 2012). Surface hardness of chemically modified wood is often increased as reported for acetylated wood (Larsson and Simonson, 1994), furfurylated wood (Lande et al., 2004, Esteves et al., 2011), DMDHEU treated wood (Emmerich et al., 2017), or melamine resin impregnated wood (Behr et al., 2017). In contrast, the hardness of thermally modified wood is reduced (Gunduz et al., 2009, Meyer et al., 2011).

Wooden floorings are exposed to various physical, mechanical, chemical, and finally biological loads especially if they are exposed outdoors (Brischke, 2010). Due to its hygroscopic character, moisture dynamics find a response in swelling and shrinking of floor boards. Hereby, the anisotropy of wood can lead to drastic deformations and warping of whole decks. Cell wall modification of wood has the potential to reduce such dimensional changes (Hill, 2006). Furthermore, aesthetic impairments of wood surfaces can result from UV degradation combined with leaching of lignin fragments and colonization of dark coloured molds leading to more or less homogeneous graying of the surface. In addition, some wood materials, e.g. sapwood portions, are susceptible to discoloration by blue stain fungi (Huckfeldt, 2009). However, all these biophysical degradation processes have in common that they affect the optical appearance only; the functionality of the flooring will not be compromised.

In contrast, mechanical loads occur in terms of wear, abrasion, and erosion and can significantly impact on the functional performance of wooden flooring. The wear effect of walking persons is often intensified by abrasive particles, e.g. sand, dust, winter grit, and other more or less sharp-edged particles. The resistance against abrasion strongly depends on the material - anatomic differences become evident, e.g. in the form of washboard effect as a result of differences between earlywood and latewood (Sell and Feist, 1986). A standardized method for determining the abrasion resistance of solid wood is still lacking. Hence, the Taber Abraser method, as referred to by EN 438-2 (2016), ISO 9352 (2012), and ASTM D 1044 (2013), has been occasionally used for this purpose, although it is originally intended for testing the abrasion resistance of high-pressure laminated papers (Militz et al., 2011). As previously shown by Welzbacher et al., (2009), the loads occurring during Taber Abraser tests provoked by rotating sandpaper under defined grinding pressure do not necessarily reflect the exposure conditions of an outdoor exposed flooring, for example a terrace decking. As shown for timber structures in the marine environment by Brischke et al. (2005) and Williams et al. (2010), it is rather necessary to use a set of test methods to fully reflect the insitu conditions to which wood is exposed outdoors. Brischke et al. (2014) applied the so-called Shaker method for testing the abrasion resistance of wet and dry wood specimens made from various wood species and found that the abrasion resistance of wood is generally increasing with higher densities. However, they also reported about exceptions such as Douglas fir (Pseudotsuga menziesii Franco) that reveals high abrasion resistance at rather moderate density. Apparently, anatomical features such as the regularly alternating early and latewood sections of Douglas fir positively affect its abrasion resistance, which is in line with a theory of shockabsorbance effects formulated by Williams et al. (2010). Similar tests using a concrete mixer and shingles were performed by Williams et al. (2010) to characterize the performance of different wood species used for groynes.

The Shaker method has been previously applied on thermo-mechanically densified and thermally modified wood, which showed significantly increased abrasion compared to untreated wood (Wehsener et al., 2017). Earlier work by Baird (2007), Militz et al. (2011) and Mahnert (2013) indicated that different kinds of chemical wood cell wall modification have an effect on the abrasion resistance of wood as well. The aim of this study was, therefore, to determine the abrasion resistance of differently chemically and thermally modified timber in comparative tests using the Taber Abraser and the Shaker test method.

\section{MATERIALS AND METHODS}

\section{MATERIJALI I METODE}

\subsection{Materials}

2.1. Materijali

Specimens were prepared from differently modified Scots pine sapwood (Pinus silvestris L.) and European beech (Fagus sylvatica L.) as well as untreated reference specimens from both wood species as shown in Table 1. Thermal modification was conducted at 230 ${ }^{\circ} \mathrm{C}$ by Timura Holzmanufaktur (Rottleberode, Germany) using the $\mathrm{Vacu}^{3}$ - process.

Heat treated beech wood was additionally modified with methylolated melamine formaldehyde resin (MMF) Madurit MW 840/75WA (Ineos Melamines $\mathrm{GmbH}$, Germany). Boards were impregnated in an impregnation plant at -0.60 mbar for $0.5 \mathrm{~h}$ followed by a pressure phase of 12 bar for $2 \mathrm{~h}$. Specimens were dried and cured in a laboratory oven at maximum temperature of $120{ }^{\circ} \mathrm{C}$ for $24 \mathrm{~h}$.

Commercially sized boards of beech were acetylated in the plant of Accsys Technologies in Arnhem, the Netherlands, using an industrial process. Prior to and after the acetylation, the dimensions and weight of the boards were measured. Since the process was not adapted, the acetylated beech showed a high amount of surface checks, but in general the degree of modification was uniform to high levels.

The modification process of furfuylation was carried out at KEBONY, Skien, Norway. Boards of beech 
....... Brischke, Ziegeler, Bollmus: Abrasion Resistance of Thermally and Chemically ...

Table 1 Wood materials under test

Tablica 1. Ispitivani drvni materijali

\begin{tabular}{|c|c|c|c|c|}
\hline $\begin{array}{l}\text { Wood species } \\
\text { Vrsta drva }\end{array}$ & $\begin{array}{l}\text { Botanical } \\
\text { name } \\
\text { Botanički } \\
\text { naziv }\end{array}$ & Treatment / Modifikacija & $\begin{array}{c}\text { Abbreviation } \\
\text { Oznaka }\end{array}$ & $\begin{array}{l}\text { Weight percent } \\
\text { gain, } \% \\
\text { Postotak porasta } \\
\text { mase, } \%\end{array}$ \\
\hline \multirow{6}{*}{$\begin{array}{l}\text { European beech } \\
\text { obična bukva }\end{array}$} & \multirow{6}{*}{$\begin{array}{l}\text { Fagus } \\
\text { sylvatica } \mathrm{L} .\end{array}$} & None / nemodificirano & Beech & - \\
\hline & & thermally modified / toplinski modificirano & Beech TMT & - \\
\hline & & $\begin{array}{l}\text { thermally modified and melamine resin } \\
\text { modificirano toplinski i melaminskom smolom }\end{array}$ & Beech TMT + M & 15.4 \\
\hline & & melamine resin / modificirano melaminskom smolom & Beech M & 16.7 \\
\hline & & acetylated / acetilirano & Beech AC & 20.7 \\
\hline & & furfurylated / furfurilirano & Beech FA & 30.3 \\
\hline \multirow{2}{*}{$\begin{array}{l}\text { Scots pine } \\
\text { sapwood / bjeljika } \\
\text { običnog bora }\end{array}$} & \multirow{2}{*}{$\begin{array}{l}\text { Pinus } \\
\text { silvestris L. }\end{array}$} & none / nemodificirano & Pine & - \\
\hline & & $\begin{array}{l}\text { modified Dimethylol - dihydroxy - ethyleneurea } \\
\text { treated / modificirano mDMDHEU-om }\end{array}$ & Pine mDMDHEU & 19.4 \\
\hline
\end{tabular}

were impregnated with furfuryl alcohol and subsequently dried and cured in an industrial plant.

Scots pine sapwood boards were impregnated in an autoclave at -0.98 bar for $1 \mathrm{~h}$ and at 12 bar for $2 \mathrm{~h}$ with a solution of modified 1.3-dimethylol-4.5-dihydroxyethyleneurea (mDMDHEU) in the following concentration: $36 \%$ of mDMDHEU stock solution and $2 \%$ magnesium nitrate hexahydrate relative to the mass of mDMDHEU as catalyst. After impregnation, the samples were cured in steam atmosphere at $120^{\circ} \mathrm{C}$. The mean weight percent gain (WPG) was $19.4 \%$.

\subsection{Determination of oven-dry density}

\subsection{Određivanje gustoće apsolutno suhog drva}

Specimens of 35 (ax.) x $8.5 \times 8.5 \mathrm{~mm}^{3}$ were oven dried at $103{ }^{\circ} \mathrm{C}$ till constant mass, weighed to the nearest $0.01 \mathrm{~g}$, and the dimensions were measured to the nearest $0.01 \mathrm{~mm}$. The oven dry density was calculated according to Eq. 1:

$$
\rho_{0}=\frac{m_{0}}{V_{0}}\left[\frac{g}{\mathrm{~cm}^{3}}\right]
$$

$\rho_{0}$ - oven-dry density $\left(\mathrm{g} / \mathrm{cm}^{3}\right)$

$m_{0}-$ oven-dry mass (g)

$V_{0}$ - oven-dry volume $\left(\mathrm{cm}^{3}\right)$

\subsection{Abrasion resistance tests - Shaker method}

2.3. Ispitivanje otpornosti na habanje - metoda Shaker

The resistance against abrasion was determined according to the Shaker method described by Brischke et al. (2005). Five oven-dry specimens of (35 (ax.) x $8.5 \times 8.5) \mathrm{mm}^{3}$ were laid in polyethylene flasks $(V=$ $500 \mathrm{ml}$ ) together with $400 \mathrm{~g}$ stainless steel balls of 6 $\mathrm{mm}$ diameter and moved in an overhead shaker at 28 revolutions $\mathrm{min}^{-1}$ for $72 \mathrm{~h}$. In total, five by five specimens of each material were tested. Distances $d$ between opposite corners of the oven-dried specimens were measured to the nearest $0.01 \mathrm{~mm}$ before and after abrasion. The percentage loss in dimension $\Delta d$ was determined as a measure of abrasion according to the following Eq. 2 for each block and an average determined:

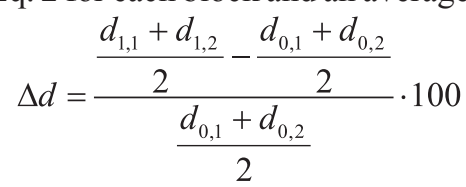

$\Delta d$ - abrasion (\%)

$d_{0,1}$ - diagonal 1 , before abrasion $(\mathrm{mm})$

$d_{0,2}$ - diagonal 2, before abrasion $(\mathrm{mm})$

$d_{1,1}-$ diagonal 1 , after abrasion $(\mathrm{mm})$

$d_{1,2}$ - diagonal 2, after abrasion (mm)

\subsection{Abrasion resistance tests - Taber Abraser} method

2.4. Ispitivanje otpornosti na habanje - metoda Taber abraser

The resistance against abrasion was determined according to the Taber Abraser method (EN 438-2, 2005). The following modifications of the Taber Abraser test were made in order to allow testing of solid wood: Specimens of (100 (ax.) x $100 \times 7) \mathrm{mm}^{3}$ were prepared and conditioned at $20^{\circ} \mathrm{C} / 65 \% \mathrm{RH}$. The tree rings of all specimens were oriented $45^{\circ}$ to their cutting edges. After weighing and measuring the thickness at four points, the specimens $(n=5)$ were clamped into the Taber Abraser and abraded with sanding paper S-42 with approx. 60 $\mathrm{min}^{-1}$ for 1,000 revolutions. Afterwards, the decrease in thickness by abrasion was determined. The percentage loss in thickness $\Delta t$ was determined as a measure of abrasion according to the following Eq. 3 for each specimen and an average determined:

$$
\Delta t=\frac{t_{0}-t_{1}}{t_{0}} \cdot 100
$$

$\Delta t$-abrasion (\%)

$t_{0}-$ thickness, before abrasion $(\mathrm{mm})$

$t_{1}$ - thickness, after abrasion $(\mathrm{mm})$

\section{RESULTS AND DISCUSSION 3. REZULTATI I RASPRAVA}

The abrasion resistance of wood was significantly affected by different modification processes, but the respective effect was strongly dependent on the method applied for testing the resistance to abrasion. Abrasion according to the Taber Abraser method was expressed as percentage reduction in thickness of the specimens $(\Delta t)$ and decreased with increasing oven-dry density of the wood material (Figure 1). Thermal modification and modification with mDMDHEU led to a decrease in abrasion resistance according to the Taber Abraser method compared to the untreated references, 


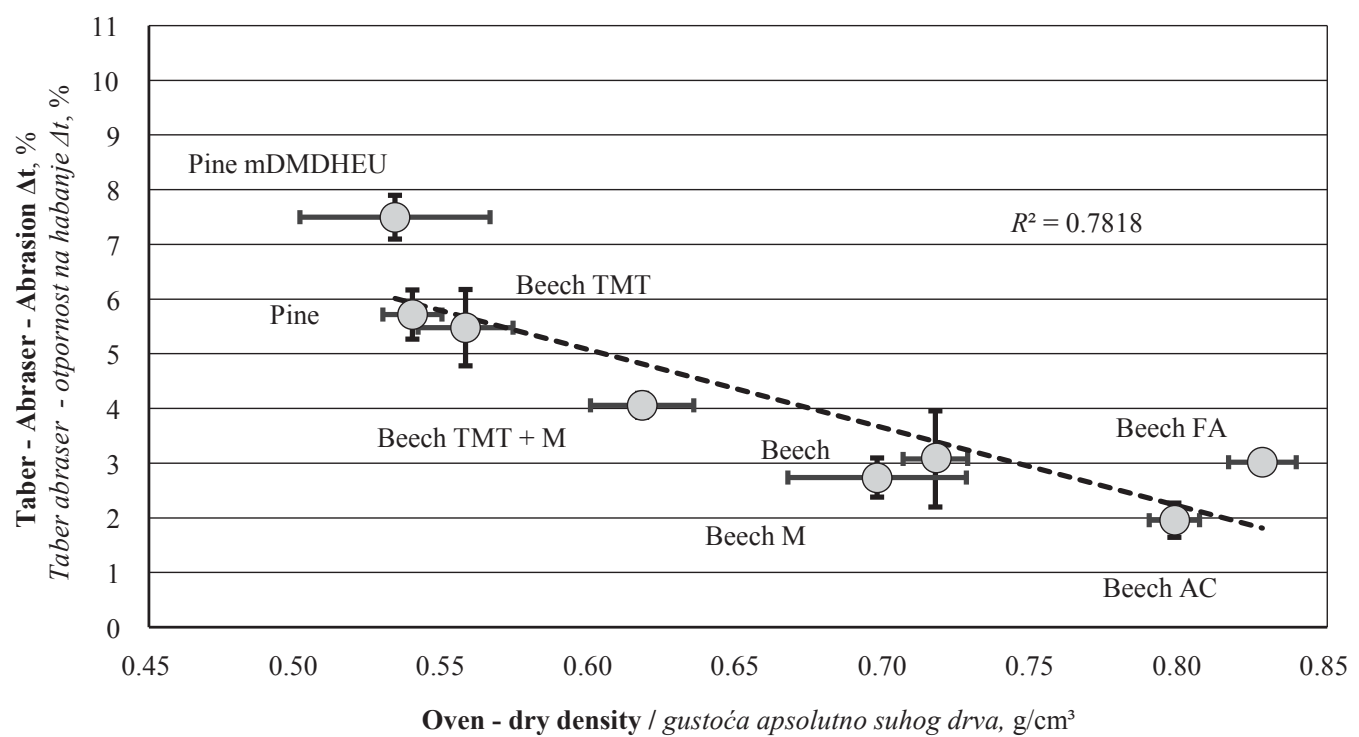

Figure 1 Relationship between oven-dry density and abrasion according to Taber Abraser method. Dots represent mean values per wood species. Standard deviation is indicated by error bars.

Slika 1. Odnos između gustoće apsolutno suhog drva i otpornosti na habanje prema metodi Taber abraser. Točke predočuju srednje vrijednosti za pojedine vrste drva. Standardna je devijacija označena trakom pogreške.

which coincides with previous findings by Emmerich et al. (2017) and Brischke et al. (2012), who reported on increased brittleness of these materials. In contrary, acetylation improved the abrasion resistance of wood. Furfurylation and an impregnation with melamine resin did not affect the abrasion of wood significantly, but a melamine treatment of heat treated beech led to an improvement of its abrasion resistance.

Abrasion of specimens challenged by shaking together with abrasive steel balls according to the Shaker method was clearly not correlated with the oven-dry density of the material. While the lighter wood of Scots pine showed clearly higher abrasion in the Taber Abraser compared to beech wood, both wood species showed only insignificantly different abrasion in the Shaker test (Figure 2). Only, acetylation led to a slight increase in abrasion resistance of wood, all other modification pro- cesses reduced its abrasion resistance. Scots pine treated with mDMDHEU, thermally modified beech with and without subsequent melamine treatment suffered from the highest abrasion in Shaker tests. The effect of the different modifications on the abrasion resistance of wood coincided fairly well with previous findings by Brischke et al. (2012) who reported that the structural integrity of wood was negatively affected by cell wall modification in the following order: Furfurylation < melamine resin treatment $<$ mDMDHEU treatment.

Consequently, it was expected that abrasion determined with the help of both test methods was not correlated as shown in Figure 3. Acetylated beech showed less abrasion, and mDMDHEU treated Scots pine the most, if considering both methods. The test material was differently challenged by the two test methods. In the Taber Abraser, wood specimens were subject to cutting

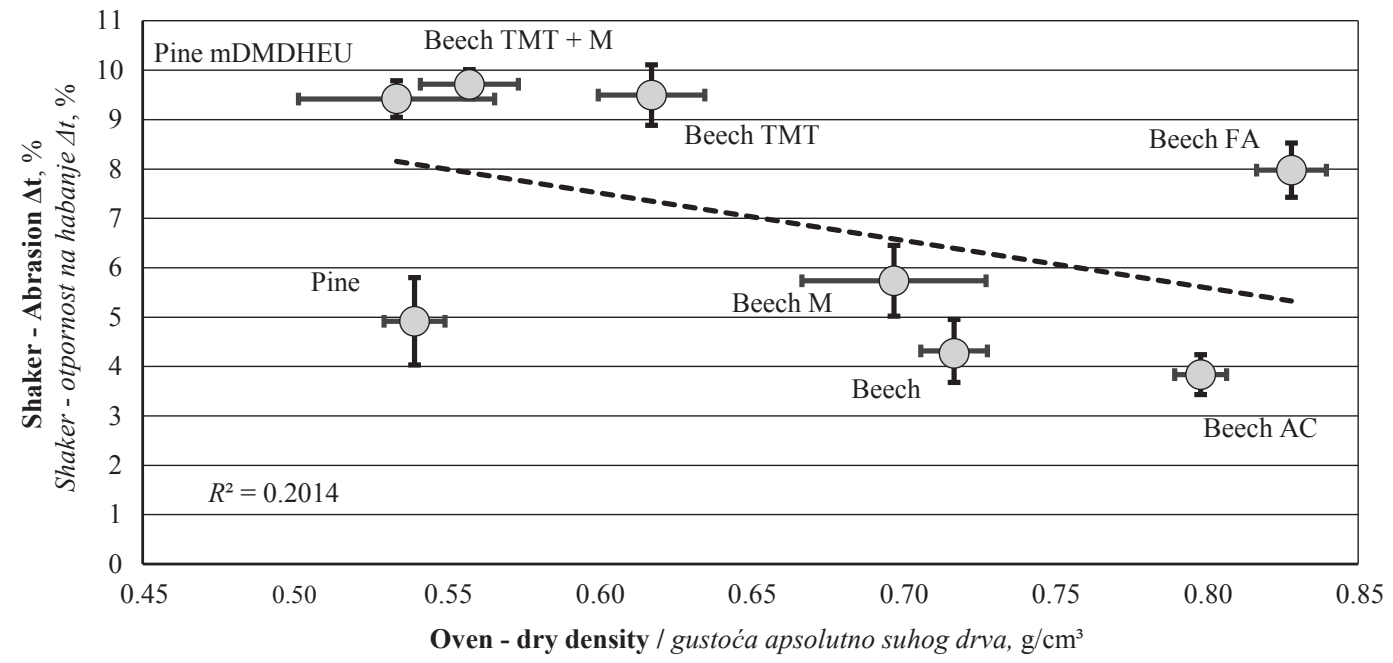

Figure 2 Relationship between oven-dry density and abrasion according to the Shaker method. Dots represent mean values per wood species. Standard deviation is indicated by error bars.

Slika 2. Odnos između gustoće apsolutno suhog drva i otpornosti na habanje prema metodi Shaker. Točke predočuju srednje vrijednosti za pojedine vrste drva. Standardna je devijacija označena trakom pogreške. 


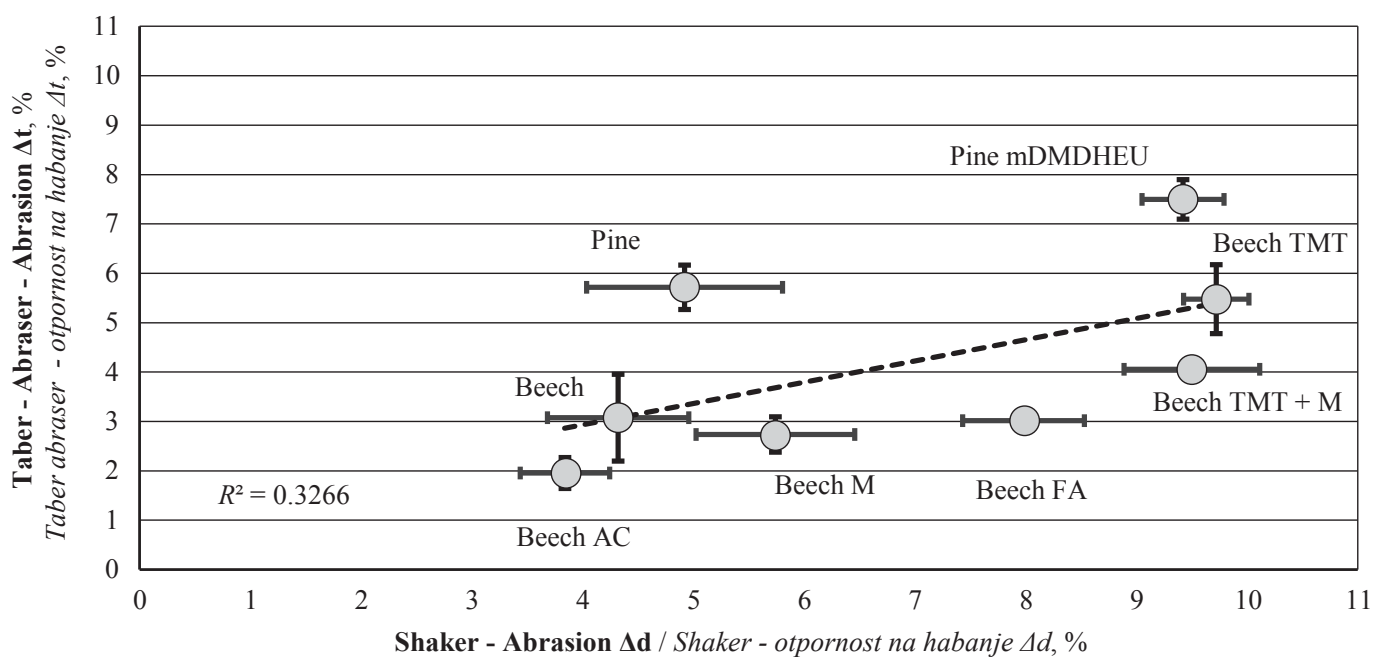

Figure 3 Relationship between oven-dry density and abrasion according to the Shaker method. Dots represent mean values per wood species. Standard deviation is indicated by error bars.

Slika 3. Odnos između gustoće apsolutno suhog drva i otpornosti na habanje prema metodi Shaker. Točke predočuju srednje vrijednosti za pojedine vrste drva. Standardna je devijacija označena trakom pogreške.
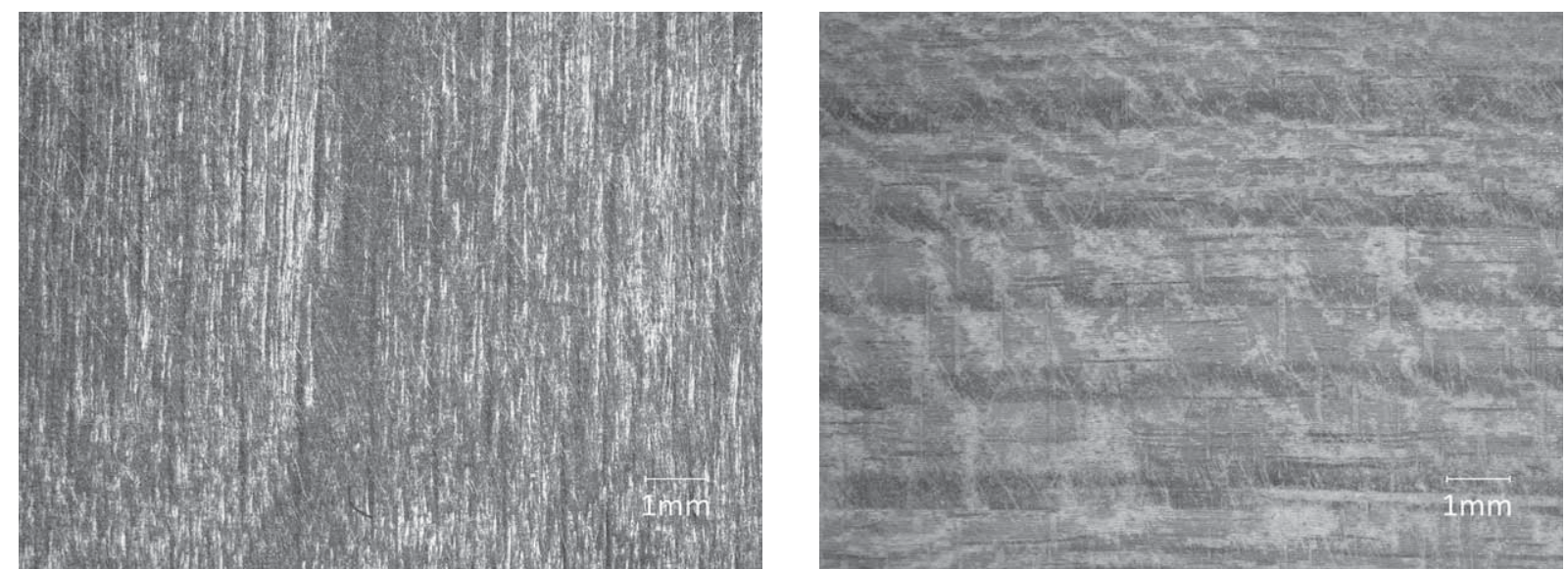

Figure 4 Scratched surface of test specimens after 1,000 revolutions in a Taber Abraser

Slika 4. Izgrebena površina uzoraka nakon 1000 ciklusa ispitivanja na uređaju Taber abraser

by aluminium oxide abrasive on the sanding paper, which is applied under pressure and a rotational movement. This particular type of wear becomes evident by crosswise cutting traces on the specimens' surfaces as shown in Figure 4. In contrast, the steel balls used for the Shaker test caused a multiple, but slight dynamic impact on the specimens, to which their longitudinal edges were particularly subjected and suffered from break offs. The rounding of the specimens' edges can be seen from their cross sections as illustrated in Figure 5.

In accordance with the percentage abrasion, two groups of materials can be distinguished by visual appearance: Untreated Scots pine and beech as well as melamine treated and acetylated beech showed only slight rounding of edges, while furfurylated, thermally modified beech with and without melamine treatment

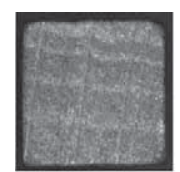

Beech

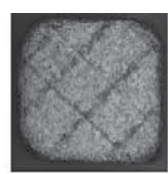

Beech

TMT

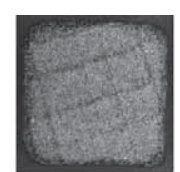

Beech

$\mathrm{TMT}+\mathrm{M}$

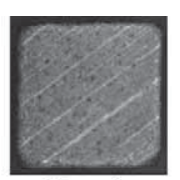

Beech as well as mDMDHEU-treated Scots pine had significantly rounded edges.

Wooden flooring in use under outdoor conditions can suffer from both scratching and dynamic loads transversally to the surface leading to break offs and rounding of edges. To characterize the suitability of wood-based materials, especially treated and modified wood, consequently requires the application of different test methods reflecting the full spectrum of loads occurring in practice.

\section{CONCLUSIONS}

4. ZAKLJUČAK

Wood cell wall modification had generally a significant and mostly negative effect on the abrasion resist-

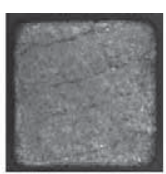

Beech

$\mathrm{AC}$

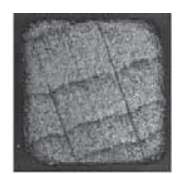

Beech

FA

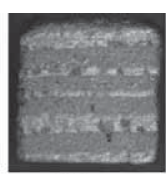

Pine

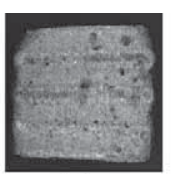

Pine mDMDHEU

Figure 5 Cross section of Shaker test specimens after $72 \mathrm{~h}$ abrasion

Slika 5. Poprečni presjek uzoraka ispitivanih na uređaju Shaker nakon 72 sata habanja 
ance of wood, but was strongly dependent on the type of modification and the test method applied. The Taber Abraser method caused crosswise cutting into the wood surface. In contrast, the Shaker method challenged mainly the specimen edges with dynamic loads. Both types of wear occur frequently in practice when wooden floorings are exposed outdoors. In addition, further parameters, such as static and dynamic hardness, as well as susceptibility to deformations and their possible impact on wooden flooring, have the potential to interact with abrasion resistance. Future research will, therefore, focus on comparative analysis of wear parameters obtained in laboratory tests and under real exposure conditions.

\section{REFERENCES}

\section{LITERATURA}

1. Baird, B. R., 2007: Dimensional stabilization of wood by vapor phase chemical treatments. Wood and Fiber Science, 1: 54-63.

2. Behr, G.; Bollmus, S.; Gellerich, A.; Militz, H., 2017: Improvement of mechanical properties of thermally modified hardwood through melamine treatment. Wood Material Science \& Engineering.

https://doi.org/10.1080/17480272.2017.1313313.

3. Brischke, C., 2010: Service life prediction of outdoor wooden decking and flooring. In: Littmann, K. (ed.): Proceedings of $7^{\text {th }}$ International Colloquium "Industrial Floors", Stuttgart/Ostfildern, 14-16 December 2010: 431-440.

4. Brischke, C.; Iseler, N.; Meyer, L.; Sawyer, G., 2014: Testing the mechanical resistance of timber used for construction in the marine environment. International Wood Products Journal, 5: 39-49. https://dx.doi.org/10.1179/2042645313Y.0000000050.

5. Brischke, C.; Koch, S.; Rapp, A. O.; Welzbacher, C. R., 2005: Surface properties of thermally treated wood Wear, abrasion and hardness. In: Militz, H.; Hill, C. A. S. (eds.): Wood modification: Processes, properties and commercialization. Proceedings of the $2^{\text {nd }}$ European Conference on Wood Modification, Göttingen, Germany, 6-7 October 2005: 371-375.

6. Brischke, C.; Zimmer, K.; Ulvcrona, T.; Bollmus, S.; Welzbacher, C. R.; Thomsen, O., 2012: The impact of various modification processes on the structural integrity of wood. Proceedings of the $6^{\text {th }}$ European Conference on Wood Modification, Ljubljana, Slovenia, 17-18 September 2012: 91-98.

7. Emmerich, L.; Bollmus, S.; Militz, H., 2017: Wood modification with DMDHEU (1.3-dimethylol-4.5-dihydroxyethyleneurea) - State of the art, recent research activities and future perspectives. Wood Material Science \& Engineering. https://doi.org/10.1080/17480272.2017.1417907.

8. Epmeier, H.; Westin, M.; Rapp, A. O., 2004: Differently modified wood: Comparison of some selected properties. Scandinavian Journal of Forest Research, 19 (sup 5), 31-37. https://doi.org/10.1080/02827580410017825.

9. Esteves, B.; Nunes, L.; Pereira, H., 2011: Properties of furfurylated wood (Pinus pinaster). European Journal of Wood and Wood Products, 69 (4): 521-525. https://doi.org/10.1007/s00107-010-0480-4.

10. Gunduz, G.; Korkut, S.; Aydemir, D.; Bekar, Í., 2009: The density, compression strength and surface hardness of heat treated hornbeam (Carpinus betulus L.) wood. Maderas. Ciencia y tecnología, 11 (1), 61-70. http://dx.doi.org/10.4067/S0718-221X2009000100005.
11. Hill, C. A., 2006: Wood modification: chemical, thermal and other processes. John Wiley \& Sons.

12. Huckfeldt, T., 2009: Bläuepilze. Europäischer Sanierungskalender. Beuth, Berlin.

13. Lande, S.; Westin, M.; Schneider, M., 2004: Properties of furfurylated wood. Scandinavian Journal of Forest Research, 19 (5): 22-30. https://doi.org/10.1080/0282758041001915.

14. Larsson, P.; Simonson, R., 1994: A study of strength, hardness and deformation of acetylated Scandinavian softwoods. Holz als Roh- und Werkstoff, 52 (2): 83-86. https://doi.org/10.1007/BF02615470.

15. Mahnert, K. C., 2013: Entwicklung eines nichttragenden Bodenbelages für den Schiffbau auf Basis ausgewählter Verfahren der Holzmodifizierung. Dissertation, University of Goettingen.

16. Meyer, L.; Brischke, C.; Welzbacher, C. R., 2011: Dynamic and static hardness of wood: method development and comparative studies. International Wood Products Journal, 2 (1): 5-11. https://doi.org/10.1179/2042645311Y.0000000005.

17. Militz, H.; Mahnert, K.-C.; Luessen, F., 2011: Method for Treating Wood and Wood-Based Materials, and Wood and Wood-Based Materials Obtainable Therewith. U.S. Patent No. 20130298814A1. 10 November 2011.

18. Sell, J.; Feist, W. C., 1986: Role of density in the erosion of wood during weathering. Forest Products Journal, 36 (3): 57-60.

19. Shida, S.; Saito, Y., 2007: Effects of heat treatment on brittleness of Styrax tonkinensis wood. Journal of Wood Science, 53 (3), 181-186. https://doi.org/10.1007/s10086-006-0841-0.

20. Tjeerdsma, B. F.; Boonstra, M.; Pizzi, A.; Tekely, P.; Militz, H., 1998: Characterisation of thermally modified wood: molecular reasons for wood performance improvement. Holz als Roh- und Werkstoff, 56 (3): 149. https://doi.org/10.1007/s001070050287.

21. Welzbacher, C.; Brischke, C.; Rapp, A.; Koch, S.; Hofer, S., 2009: Performance of thermally modified timber (TMT) in outdoor application-durability, abrasion and optical appearance. Drvna industrija 60 (2): 75-82. https://doi.org/10.15488/2011.

22. Wehsener, J.; Brischke, C.; Meyer-Veltrup, L.; Hartig, J.; Haller, P., 2017: Physical, mechanical and biological properties of thermos-mechanically densified and thermally modified timber using the Vacu3-process. European Journal of Wood and Wood Products. https://doi.org/10.1007/s00107-017-1278-4.

23. Williams, J. R.; Meaden, M.; Simm, J.; Dupray, S., 2010: Assessment of the durability and engineering properties of lesser-known hardwood timber species for use in marine and freshwater construction. TRADA Technology Ltd, Environment Agency, HR Wallingford, UK.

24. ***ASTM D 1044, 2013: Standard Test Method for Resistance of Transparent Plastics to Surface Abrasion.

25. ***EN 438-2, 2016: High-pressure decorative laminates (HPL) - Sheets based on thermosetting resins (usually called laminates) - Part 2: Determination of properties.

26. ***ISO 9352, 2012: Plastics - Determination of resistance to wear by abrasive wheels.

\section{Corresponding address:}

\section{PD Dr. CHRISTIAN BRISCHKE}

University of Goettingen

Faculty of Forest Sciences and Forest Ecology

Wood Biology and Wood Products

Buesgenweg 4, D-37077 Goettingen, GERMANY

e-mail: christian.brischke@uni-goettingen.de 